\title{
7
}

\section{DRAWING THE CITY}

\section{Form and Meaning}

\section{Lamberto Amistadi}

It is now commonly known that cities, like facts, also only exist once they have been depicted, and that this depiction is the result of an act of voluntary determination, which selects certain elements while excluding others.

A long tradition of urban studies in Italy ${ }^{1}$ has sought to identify the conceptual categories on the basis of which to select those elements to be represented - that is, the signs to be drawn on paper - that would bring the city's drawing closer to the architectural design. To do this, the destiny of architecture had to be intertwined with that of the city so that architecture not only indicated the work or discipline, but the city itself is understood as an architectural work. If the city is a work, then the language of description (Amistadi 2012b) must represent the physical reality of the facts, in the sense of what has been done, urban artifacts $^{2}$ with their specific form and individuality. On the contrary, what must be excluded from the drawing are the elements of the city lacking practical and aesthetic intentionality, that is, elements without meaning. The intended image thus obtained will not only show the relationship between the urban artifacts, and between the artifacts and the parts of the city, but also the willingness of the city itself to be transformed starting from the definition of its stable and permanent elements. Through patient decoding and recoding work, the city's drawing and architectural and urban composition redefine the playing field in which architecture operates and reaffirm its strategic role in the city's design.

\section{Form}

I would like to start with a beautiful drawing of Padua made by a working group led by Professor Eleonora Mantese at IUAV in Venice commissioned by - so to speak - the edition of the Festival of Architecture ${ }^{3}$ entitled European City Architecture. Structure, Project, Image (Amistadi and Prandi 2011). In a certain sense, the edition was the premise for the ArchéA project (for at least three out of five of the partners; Figure 7.1). 


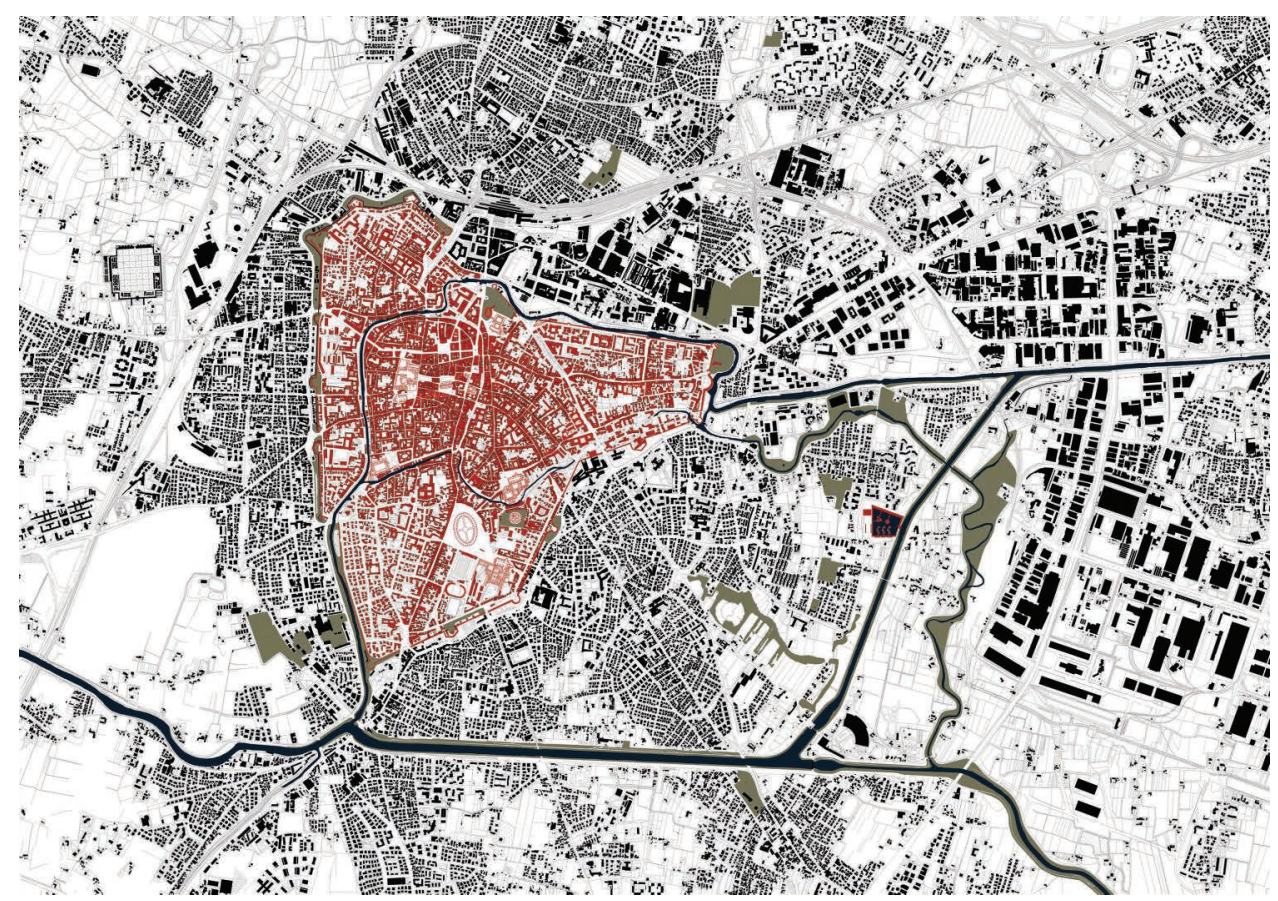

FIGURE 7.1 Drawing of the city of Padua with the area of the Historic Center in red. Original drawing in 1:5,000 scale. Degree Workshop: City of Padua. Supervisor: E. Mantese. Coexaminers: C. Eusepi, G. Rakowitz, U. Rossi. Graduates: A. Meneghin, M. Perbellini, S. Vialetto, A. Tambè.

We can interpret the red color highlighting the Historic Center in the drawing in various ways:

a These nuclei of the concentrated city can simply represent - as Giuseppe Samonà wrote (1980, 16; Amistadi 2012, 69) in an essay entitled How to start over. The territory of the extended city according to a new form of urban planning - "images that acquire a particular expressive value, almost large natural fragments full of history."

b Or the red nucleus of this drawing of Padua can represent a concrete and exemplary model of a type of open space to be taken as a reference point that is both quantitative (density, distances) and qualitative (the shape of open spaces in relation to the shape of the blocks), not necessarily to aspire to, but certainly to take measurements in progressive and strategic terms. It is said in these cases that the impossible - that is, the impossibility of replicating the spatiality typical of historic centers as in the contemporary city - becomes the measurement of that which is possible.

c This red nucleus can also have a third meaning: to in some way represent the idea of a part of a city, the idea or possibility of building a part of a city that is morphologically complete and, as such, circumscribed and recognizable. The European Landscape Convention (CoE 2000) also speaks of "landscape" in terms of part, ${ }^{4}$ referring to a part of a territory perceived and recognized by the population on the basis of its character. That is, it places the relationship between part and recognizability, also relative to its dimension. 
Giuseppe Samonà (De Carlo and Samonà 1984) builds the Program Plan of the Historic Center of Palermo starting from the idea of a mapping that detects the parts of the city based on their formal coherence. In truth, he is careful not to consider the historic city center as something that is fixed once and for all and frozen in its form. Samonà speaks of open systems and closed systems, with the systems being open or closed based on their degree of transformability. The degree of transformability is assessed on the basis of their formal completeness. In fact, these open or closed systems are formal systems understood according to both of the meanings the concept of form can assume: the autonomy of the architectural form and even of pure visibility on the one hand - Samonà compares the shape of one of these systems to that of a spoon - and the form understood as a system which is accomplished and organized in its entirety (Figure 7.2).

In truth, the formal units drawn by Samonà are more complex than a mapping based on a simple morphological approach. The parts identified by Samonà are a sort of environmental unit that he calls contexts, whose identification combines the recognition of form with a sort of cultural recognition that also touches on toponymics. That is, the goodness of the choice of the context or part of the city is suggested and certified by the fact that that part is known by a certain name: the recognition starts from certain knowledge. Luciano Semerani (2006) wrote a very beautiful text on Samonà, Giving things a name, and says: "In some of his latest studies of regulatory plans the usual colors, the usual nets that are used in urban planning gave way to writings, procedures, behaviors, words, the names of things." Even the contexts are accompanied by a description for which the formal coherence of the part must go hand in hand with the story, with what can be told. In all fairness - and this is very important the parts almost always take their name from their monumental core. The parts or systems or contexts always contain a monumental core, which works as an irradiation center, from which, from the inside out, an order and a tension are established that are reflected on the entire context. These monumental cores express a certain degree of recursiveness; that is, it could be said that they are a part just as the historic center represents the whole city.

There is another very famous drawing in which the dialectic between permanence and transformation is entrusted - so to speak - to the invariant toponymy. It is the drawing by Saverio Muratori (1960) of the Historic Center of Venice. In this case, the names are those of Saints: San Pantalon, San Tomà, Santa Margherita, San Polo, and so on (Figure 7.3).

There are many ways to read Muratori's drawings of Venice. One of these is that suggested by the drawing of Phases III and IV of Figure 7.3, where the transformations of the city over time are represented simultaneously, superimposed on the drawing sheet as if they were a set of possible solutions. In general, the topicality of the design, through an act of voluntary determination, sets the different historical times in the present by reintroducing the solutions the historical development of the city has undergone within the list of possible solutions. This unusual simultaneity, that is, being outside of historical time, is the sense in which in The Architecture of the City $(1966,1982,70)$, Aldo Rossi openly declares that "urban science is not a historical science" and in which he also stresses how the study of urban evolution can benefit from the study of toponymics: “(...) it is apparent that all cities contains numerous examples of significant physical modifications of the land which are recorded in the names of their older streets and roads."

What interests us about these two experiences - that of the drawing of the Program Plan of the Historic Centre of Palermo and that of the Muratori's drawing of Venice - is that the drawing, in both cases, takes on a strategic dimension. This strategic dimension is based on 
Delimitazione e descrizione dei contesti.
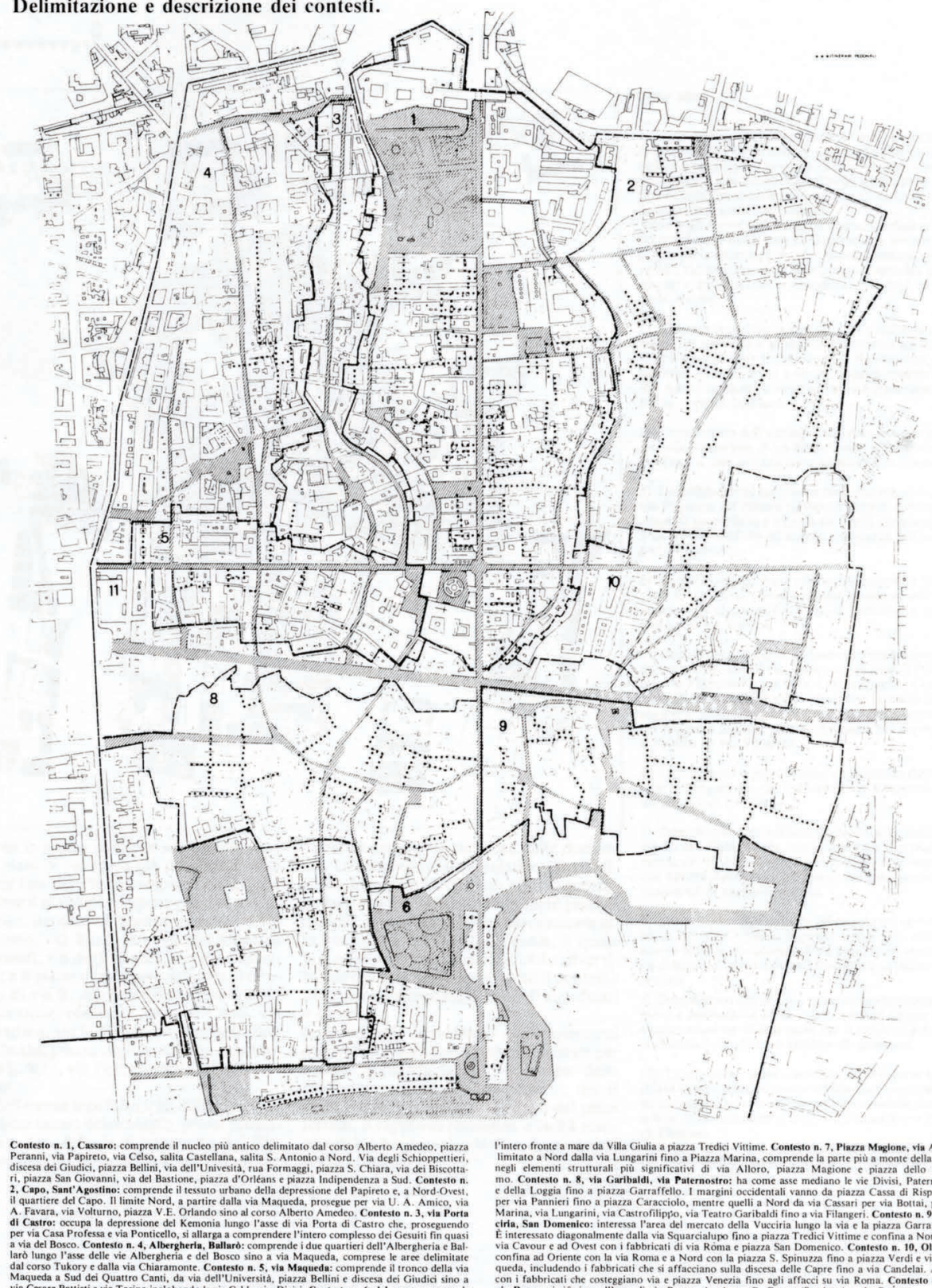

Pintero fronte a mare da Villa Giulia a piazza Tredici Vittime. Contesto n. 7, Piazza Magione, via Alloro: limitato a Nord dalla via Lungarini fino a Piazza Marima, comprende la parte più a mone, dellla Kalsa
negli elementi strutturali piü significativi di via Alloro, piazza Magione c piazza dello Spasi negli elementi strutrurali più significativi di via Alloro, piazza Magione e piazza dello Spasie della Loggia fino a piazza Garraffello. I margini oceidentali vanno da piazza Cassa di Risparmio per via Pannieri fino a piaza Caracciolo, mentre quelli a Nord da via Cassari per via Bottai, piazza charina, via Lungarini, via Castroflilipuo, via Teatro Garibaldi fino a via Filangeri. Contesto n. 9, VucE interessato diasonalmente dalla via Squarcialupo fino a piazza Tredici Vittime $e$ confina a Nord 00 via Cavour e ad Ovest con i fabbricati di via Roma e piaza San Domenico. Contesto n. 10, Ollvella:

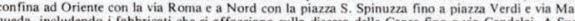
con i fabbricati che costeggiano via e piazza Veneria fino agli affacei su via Roma. Contesto n. 11

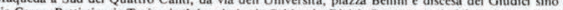
vin Roma: si riferisce all'asse di via Roma, da piazza $\mathrm{G}$. Cesare (Stazione) a via Cavout.
vian

FIGURE 7.2 Giuseppe Samonà, Giancarlo De Carlo, Program Plan of the Historic Center of Palermo, 1979-1982. Delimitation and description of contexts. Supplementary to Progettare 1, 1984. 

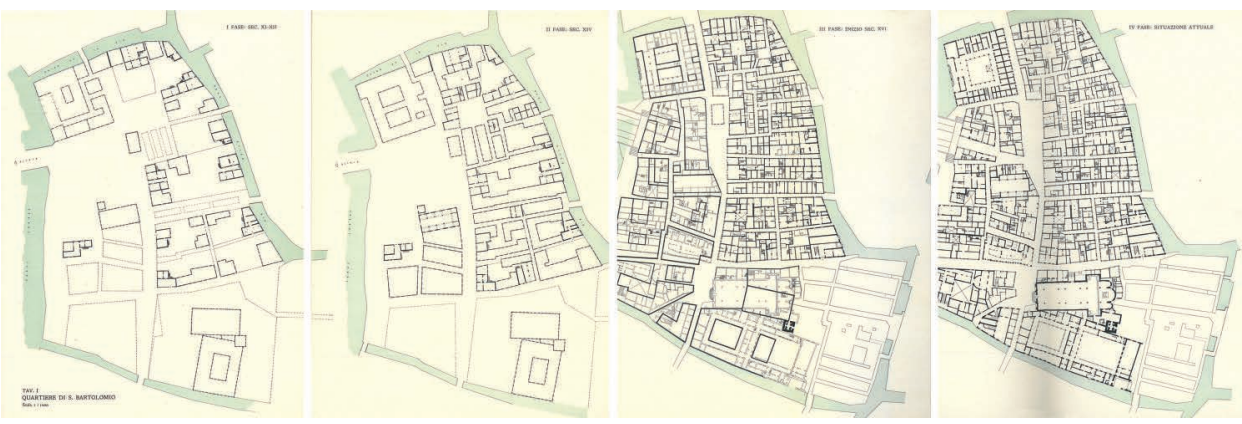

FIGURE 7.3 Saverio Muratori, Drawing of the four development phases of the San Bartolomio District in Venice. From Studi per un'operante storia urbana di Venezia (1960).

a hypothesis that corresponds to both an act of faith and to an analysis method: that the formally completed parts exist or can exist and that these parts are decisive for the quality of the urban anthropic environment. The strategy of the city by parts can act on two levels: (a) by intervening on the definition of the part, that is, on the completeness of the formally completed part, or (b) the strategy can intervene between the parts, at the level of the continuity and discontinuity of the parts themselves, that is, on the interruptions, the discontinuities precisely between one part and the other, and the white spaces around the written words of Mallarmé's poems, which emphasized the meaning of some words by leaving smaller or larger white spaces around the words themselves: I mean those portions of land that do not correspond to any classification, which are unnamed.

A strategy of this kind necessarily concerns the drawing table, as it cannot be practiced in the abstract. It is a strategy that involves the redesign of the city by addition. This is not abstraction by subtraction starting from a general technical paper, but addition in which the drawing consists of the parts and elements that can be given a name. The map consists of what is added gradually to the drawing sheet, that is, "to the city as to a sheet on which to draw." Oswald Mathias Ungers $(1997,19)$ speaks of discovery urbanism and says: "Urban art consists of finding places in the chaos of the city, giving them a name and revealing their peculiarities. It is therefore an urban art of discovery and not invention."

\section{Meaning}

I would like to now return to the topic of the continuity and discontinuity of the parts within the city, because this is the ground on which the validity of the initial hypothesis is measured, that is, that the open space of the historic center can be valid as a measurement for the evaluation and design of the contemporary city, that is, the paradoxical consideration that the method of intervention on the historic city can also be valid for the contemporary city. If the space of the historic city is a continuous space, how can a model that assumes the continuity of urban space as fundamental be valid for designing the discontinuous, open, and fragmented space of the contemporary city?

Erwin Panofsky introduces Meaning in the visual arts (1955, 24), offering as an alternative to artistic intention he calls primary that which is between open space and closed space: on the one hand bodies, understood as closed and delimited volumetric units, and, on the other, space, understood as the abstract, extended and unlimited open Cartesian space. But 
immediately afterwards Panofsky masterfully declares that the real alternative - which he calls fundamental - is not that between open space and closed space or space and body but that between differentiation and continuity. If we reformulate the description of the nature of the historic center of medium-sized European cities in terms of differentiation, we can shift attention from a spatial-quantitative connotation (continuity) to a spatial-qualitative one (the intervention of a difference within a continuous space). Carlo Aymonino is perfectly aware of this when, in Il significato delle città (Meaning of cities; 1975, 6-7), he takes up Panofsky's concept and speaks of the monument precisely in terms of differentiation:

[the monuments] Become significant relative to this or that city precisely because, first with their specific presence and then with the diversification of use, they decisively contribute to changing the partial references with respect to the whole, to the overall urban form.

That is, as specific elements included in the category of primary urban artifacts, monuments are not emergences in themselves, an end in themselves, that is, of more or less simple exceptional facts, but are significant elements of differentiation in that they retroactively act on the shape of the city, "changing its partial references with respect to the whole." In this way, the most important thing, what really characterizes the historic centers of mediumsized European cities, is no longer their spatial continuity but the wealth of significant urban artifacts that, with their differences, shape the quality of the urban space.

A corollary to the replacement of the opposing body/space pair with that of differentiation/ continuity concerns the disarticulation of the connection between monument and body; that is, the monument is not such because it is identifiable with a body understood as a three-dimensional volumetric unit, but for its meaning - its differentiating value; similarly, a volumetrically empty space is not necessarily meaningless. This is how a football field, a polo field, a wheat or dairy field, a park, a garden, a vegetable garden, a brolo (walled-in garden) also act as elements of continuity (semantics) beyond their volumetric inconsistency (Amistadi 2008). Two Polish anthropologists who in contemporary publications are considered the inventors of the concept of empty space - Jerzy Kociatkiewicz and Monika Kostera - in a beautiful article entitled The Anthropology of Empty Spaces (1999) published in a magazine with the equally interesting title Qualitative Sociology clearly explain how real emptiness is the place to which no meaning is attributed. They say,

They do not need to be physically divided by fences or barriers. They are not forbidden places, but empty spaces, inaccessible because of their invisibility - and I would say, because of their unspeakability-. If giving meaning to things is a task of modelling, understanding, redirecting surprise and creating meaning, our experience of empty spaces does not include it.

We could say that from a qualitative point of view - not of Qualitative Sociology in this case, but of Architecture - true urban continuity and true densification do not concern volumetric quantities in themselves as much as the possibility that architecture offers for building significant places. Since there has been a lot of talk about densification for some time, I have already called this type of qualitative densification semantic densification (Amistadi 2012a). 


\section{The case of Bologna}

Semantic densification means considering the fundamental role that urban artifacts play in the architecture of the city and establishing that the meaning of cities, as well as the quality of their public spaces, depends on their presence, and especially on the presence of specific urban artifacts, endowed with their own name and which are at the same time architectures and places. Because this is precisely the core of the Italian urban studies tradition, considering architecture in relation to the city.

I will provide some examples of this relationship using the city of Bologna. The first type of relationship, which is the simplest but not the least important and which corresponds to a sort of positional logic, is the positional relationship. This is the location of monuments in relation to parts of the city. It is a matter of boundary architecture or topology: urban artifacts are placed at the boundary of the parts, the inner boundary, or the outer boundary. Some monuments, such as the Monastery of San Domenico, are placed on the inner edge of the city's first circle of medieval expansion - the so-called Circle of Thousands - while others, such as the Monastery of San Francesco, are placed at its outer boundary. Entire families of monumental emergences give a rhythm to the roads that measure the distance between the first and second medieval expansion and leave the Circla through 12 gates. The convents of San Giuseppe and the Santissima Annunziata at Porta Procula and the Monastery of San Michele in Bosco are located in the belt of land between the walls of the city and the hill. The Margherita Gardens occupy the space between the Circla and the slopes of the Bologna Apennines (Figure 7.4).

But the monuments do not simply serve the passive role of emergence. On the contrary, they play an active, even germinating role in the construction of the city. Take, for example, the Monastery of San Francesco. In the early 1200s, the territory outside the Circle of Thousands was a portion of the city that had been completely destroyed by the invasion of the barbarian population of the Lombards. The Franciscan monks built their monastery on this land, aligning it with the city gate, and it is from this settlement that the city grew and developed outside the walls, growing along the streets that flank the monastery. The urban artifact thereby fulfilled a dual function: it allowed the development of the city and connected a previous part with the next as a bridge to the other. In other words, it allowed for continuous urban development. The same could be said for the eastern part of the city and for the Monastery of Santa Sofia dei Servi. The monasteries acted as catalysts for the development of the city both to the east and west (Figure 7.5).

But the role of the monuments in the city is even stronger. They have an irradiative purpose; that is, they constitute the centralities from which narrative lines are established within the city. An ideal example is the sanctuary of the Beata Vergine del Soccorso. The history of this monument is also connected to a new settlement within the city, but in this case its topological motive is different. In this case, the church was not located on the edge of the consolidated part of the city, but on the opposite edge of the new part, at the end point of the road that extended between the Circle of Thousands and the Circla and along which, around 1200, the new settlement developed starting from two rows of small houses. Since the beginning of the 1500s, the inhabitants of the village worshipped a wooden statue of the Madonna with child located exactly where the sanctuary currently stands. When the plague broke out in Bologna, the statue of the Madonna del Soccorso was carried in procession, propitiating - so it seems - the end of the plague. Every year since then a procession 


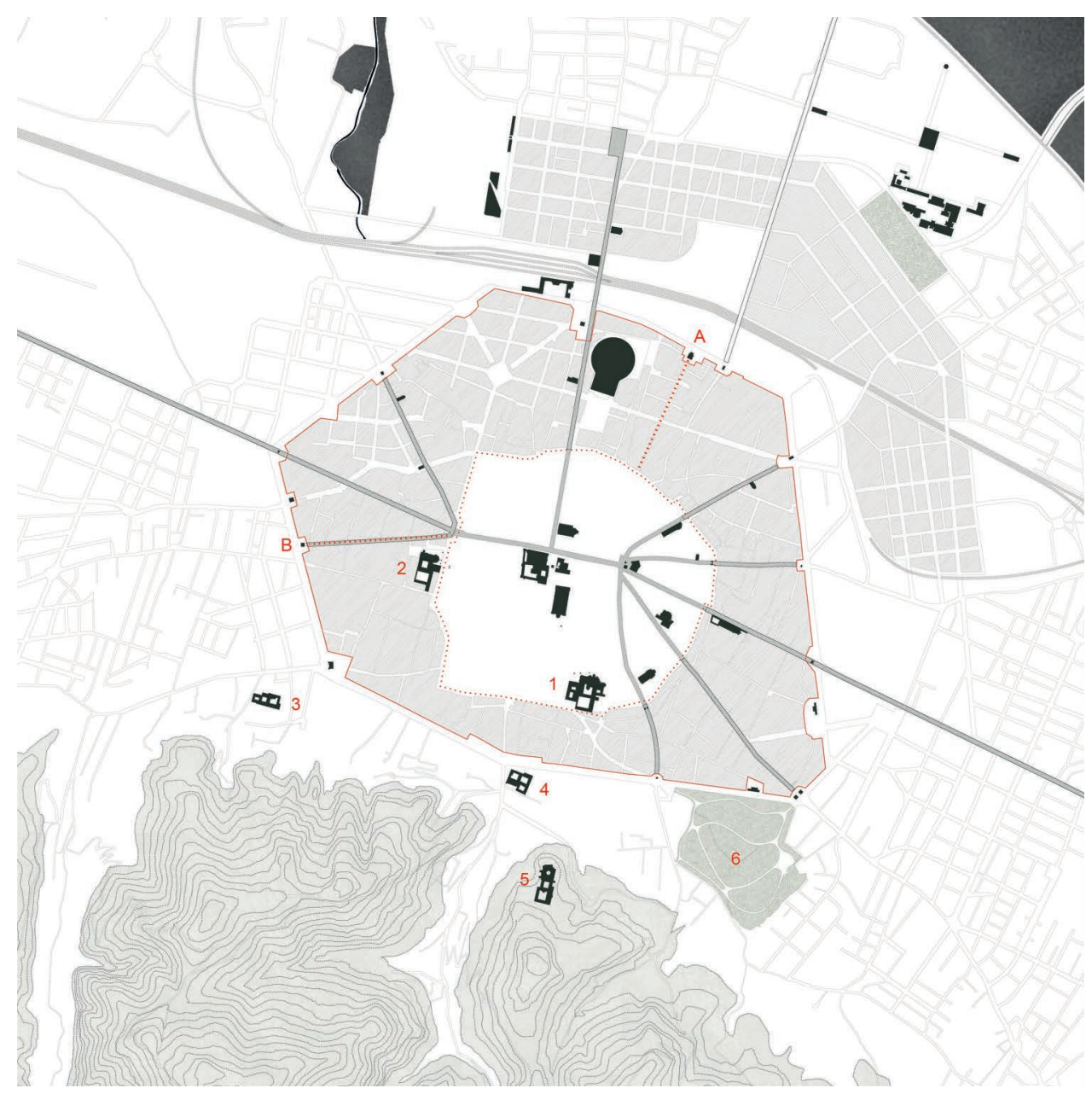

FIGURE 7.4 Drawing of Bologna with the Circle of Thousands (dashed red line in the center of the drawing), the Circla (continuous red line) and the monuments: 1. Monastery of San Domenico; 2. Monastery of San Francesco; 3. Convent of San Giuseppe; 4. Convent of the Santissima Annunziata at Porta Procula; 5. Monastery of San Michele in Bosco; 6. Margherita Gardens; the Sanctuary of Madonna del Soccorso (A) with Via del Borgo di San Pietro and the Church of San Rocco (B) with Via del Pratello. Original drawing in 1:10,000 scale. Laboratorio ArchéA.

has crossed the city to bring the statue of the Madonna to the Church of San Rocco in Borgo del Pratello on the opposite side of the city (from points A to B of Figure 7.4). Thus, the two monuments establish the extreme points within whose boundaries the ritual event takes place. Their position within the city not only assumes a syntactic meaning - marking the beginning or end of a part, in this case the road, which also becomes an accomplished and defined urban artifact - but also establishes a narrative tension between parts of the city that are distant from each other, united by the ritual of which they constitute the 


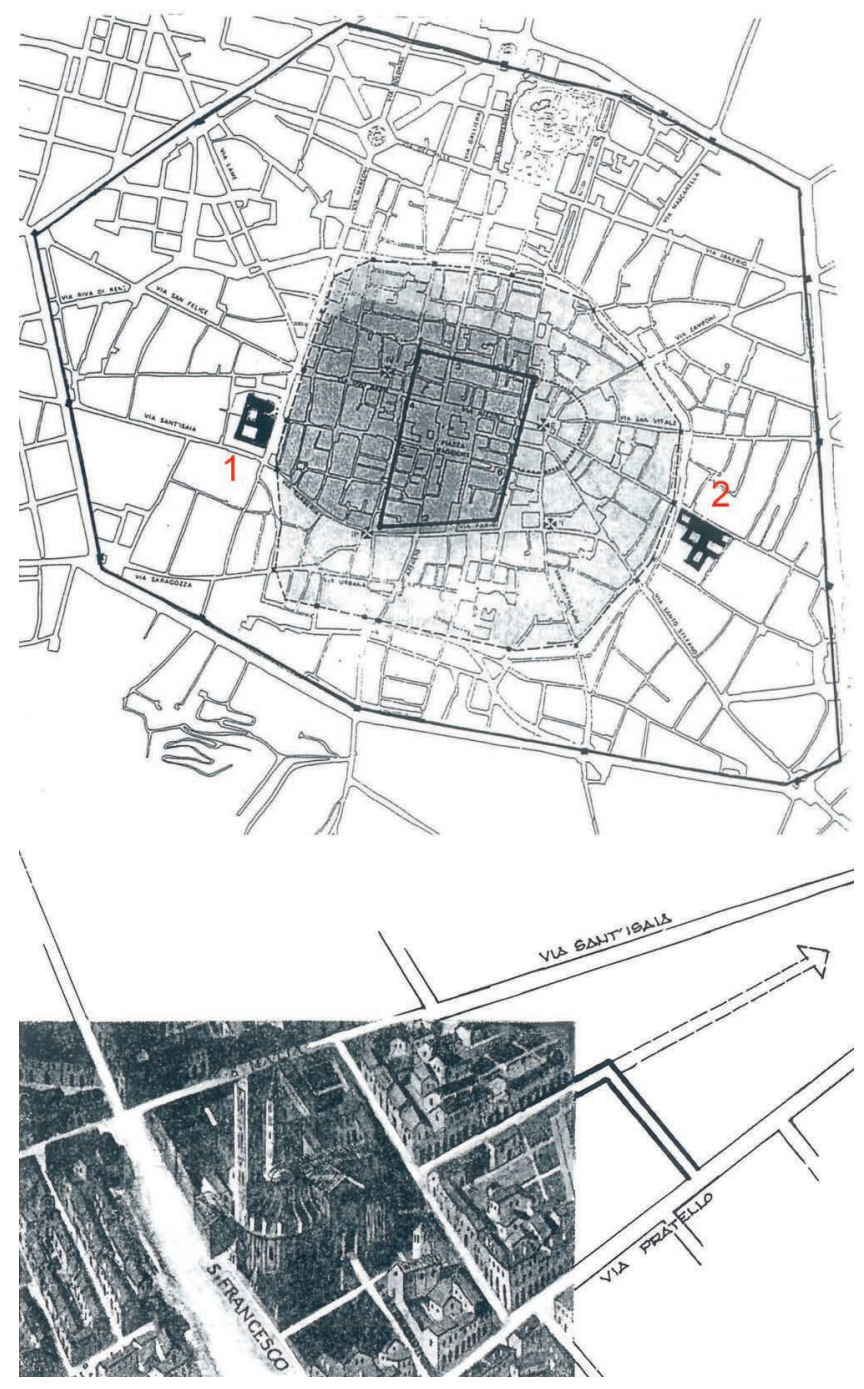

FIGURE 7.5 The position of the Monastery of San Francesco (1) and Santa Maria dei Servi (2) within the Historic Center of Bologna. Via Sant'Isaia and Via Pratello, the streets that flank the monastery, become the guidelines of urban development. From Luigi Vignali, Dall'antica perduta cattedrale a San Petronio. L'evoluzione dell'architettura sacra a Bologna (2002).

cornerstones. The sanctuary of Madonna del Soccorso demonstrates another aspect of the relationship between architecture and the city and the sacredness of places: monuments are never born from a tabula rasa but are always built instead of or on top of a previous one, in a chain of replacements whose origin has roots in the stuff of legends. In other words, they always have a revived value. Many similar examples can be made, starting from the churches that the Jesuits built above the vestiges of Aztec temples in Mexico and Central America 

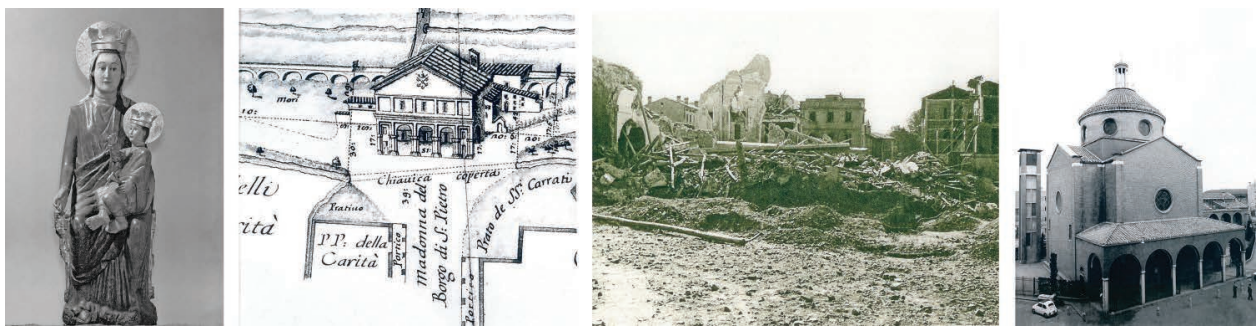

FIGURE 7.6 The wooden statue of the Madonna del Soccorso; the 16th-century church; the destruction of the sanctuary during the Second World War; the reconstruction of the church after the war.

(Amistadi 2018). Thus, the Church of Madonna del Soccorso was built in 1500 in the place where the wooden statue of the Madonna was located and had been worshipped since the previous century. And when the church was destroyed by bombings in the Second World War, it was rebuilt in the same exact spot (Figure 7.6).

But monuments also serve another purpose within the city. They act as time and space machines and can connect one place in the city with another place in another city in another time. The Basilica of Santo Stefano in Bologna is a monumental complex consisting of seven churches built over an ancient Roman temple dedicated to the cult of Isis. This monumental complex is called Sancta Hjerusalem and is built analogously with the complex of the Holy Sepulcher in Jerusalem. When the Arabs destroyed the Basilica of the Holy Sepulcher in Constantinople after the year 1000, the Benedictine monks decided to rebuild it in Bologna. Anastasis (the place of Christ's burial and resurrection) is built on the ruins of the Roman temple, as well as the Sacred Garden with the Calvarium and Martyrium and a new church representing the place of the crucifixion. Thus, Bologna and Jerusalem are spiritually interrelated by the analogy upon which their monuments are invested. Similarly, around the year 1200 on the so-called Mount Oliveto, a new church was built that corresponds to the basilica erected on the Mount of Olives in Jerusalem. The church takes the name of San Giovanni in Monte, but, in fact, the subsequent urban transformations have made the hill's presence almost imperceptible. Its existence is remembered in the name of the monument; as Aldo Rossi said, the name of the monument becomes the clue and testimony of the transformations that the city has undergone over time.

Another such example concerns the Church of Santa Maria della Visitazione al Ponte delle Lame, which is a demonstration of how the explanations behind urban transformations are often hidden in the names of monuments. In the photograph of Figure 7.7, a small church can be seen alone in the middle of an open space, seeming to have a rather strange relationship with the urban fabric. But its name offers a clue and explains the transformation that has taken place: the name Santa Maria della Visitazione al Ponte delle Lame suggests that this church was built near a bridge or that the church itself was a bridge [ponte means bridge in Italian]. In any case, there must have been some course of water. And in fact, between the Circle of Thousands and the Circla there was once a canal that crossed the road which started precisely from Porta Lame. The Church of Santa Maria della Visitazione al Ponte delle Lame stood exactly at the point of that intersection (Figure 7.7). 


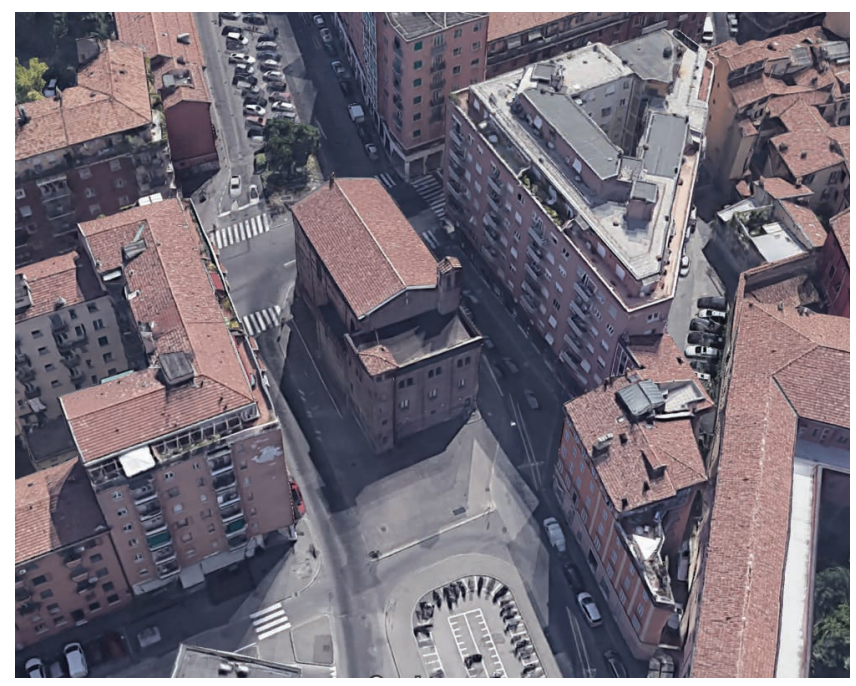

FIGURE 7.7 Church of Santa Maria della Visitazione al Ponte delle Lame.

\section{Conclusion}

This interweaving between significant architecture and the city, between urban artifacts and cities, clearly represents the so-called monumental structure of the city. The word structure emphasizes the relationship between the elements, where the relationship is more important than the elements themselves. Roland Barthes writes that - especially in our time - the most important thing is not building original objects but establishing original relationships between existing objects. Some call this interweaving figurative structure, and if we again appeal to Roland Barthes, he tells us to understand the term figure not so much in a rhetorical sense "but rather in a gymnastic and choreographic sense (...): the body of athletes, speakers, statues: that which can be immobilized of the body under stress" (1977, 5). The term offers a good idea of how architectures work within the city: they are fixed elements but determine and presuppose dynamics within the city. Figuration organizes the relationships between bodies and the position they take within a meaningful sequence. The figures carry out an orderly and continuous task even in the discontinuity and fragmentation of the context in which they are placed. It is for this reason that a drawing depicting the figurative structure of a city clearly represents its shape and meaning. Like the other expressions of material and spiritual culture, the form of the city is also subject to continuous transformation; the new image always contains the loss of the previous one. But it is precisely the unstable, changeable, and accidental nature of the urban phenomenon that allows us to grasp its stable and necessary elements.

From this point of view, the drawing of the city can only be a work that proceeds by addition, gradually - as Samonà says ${ }^{5}$ - by adding unity of meaning starting from that which is defined, accomplished, and permanent: the persistence of the paths and the roads, the urban artifacts with their individuality, the monuments with their own names: Piazza Maggiore, Basilica di Santo Stefano, Porta San Vitale, and so on within a specific city - Bologna, 
Milan, Venice, Aachen, and so on - with their specific form. Because the form is always specific. Starting from the framing and definition of the scale, "the city becomes a sheet on which to draw." This drawing has not only a representative value (i.e., it is not a question of depicting the face of the Madonna, as Le Corbusier says [1921, 1999, 35-37] about the strategic value of the planimetry), but the drawing that interests us is that particular form of drawing in which the figurative structure of the city makes the dialectic between permanence and transformation evident, that type of drawing which Giorgio Grassi and Aldo Rossi discuss $(1970,70)$ in the report for the design of the San Rocco district in Monza in which "the general case is still legible, the law that presides over the drawing." In this way, the drawing builds, indicates, or simply clarifies - without distractions, so to speak - the playing field, the starting condition, and, therefore, the number of possibilities for the design of the present and future city. This type of drawing is one in which there is a lot of free space; in a certain sense, such a drawing simply has to make space. What should the space of architecture make room for? Architecture. It can act retroactively on the same playing field, redefining its boundaries and even its rules.

But perhaps this interweaving of topology, toponymics, and topography can be better understood with the term used by Giulio Carlo Argan, narrative structure. In a beautiful essay entitled La città nel pensiero di Leon Battista Alberti (The City according to Leon Battista Alberti), Argan writes (1982, 53-54), "For Alberti, [architecture] is framed within the broader context of the city, it is the interpretation and communication of its meaning." And again, "As a representation and communication of historical-ideological contents, the city is discourse, oratory, rectory."

\section{Notes}

1 In other words, the tradition of urban studies whose best-known and most recognized outcome corresponds to the book L'architettura della città (1966, The Architecture of the City 1982) by Aldo Rossi, but which includes numerous projects and numerous other texts written between the early 1960s and the late 1970s, including: Studi per un'operante storia urbana di Venezia (Studies for an active urban history of Venice - 1960) by Saverio Muratori, La costruzione logica dell'architettura (The logical construction of architecture - 1967) by Giorgio Grassi, Gli elementi della città e lo sviluppo di Trieste nei secoli XVIII e XIX (The elements of the city and the development of Trieste in the 18th and 19th centuries - 1970) by Luciano Semerani, the collective volume La città di Padova (The city of Padua - 1970) edited by Carlo Aymonino, issue 7 (1970) of the magazine "Lotus" entitled Architettura nella formazione della citta moderna (Architecture in the formation of the modern city), Il significato della città (The meaning of the city - 1975) by Carlo Aymonino, L'architettura della realtà (The architecture of reality - 1979) by Antonio Monestiroli.

2 Aldo Rossi titles the first chapter of The Architecture of the City (1966) "The Structure of Urban Artifacts." The chapter introduces the general approach to the study and design of the city. This approach refers to the notion of urban artifact: that is, the city understood starting from "what has been done," with its specific form and its own aesthetic intent; the urban artifact can correspond to a building or a street or a place. Urban artifacts define the identity and character of a part of the city and therefore of the entire city. Urban artifacts are characterized by their architecture and form, that is, by their individuality. In other words, the urban artifact represents the "last verifiable fact" that allows approaching the study of the city in the most concrete way possible. After this, Aldo Rossi offers the example of the Palazzo della Ragione in Padua.

3 The Festival of Architecture is an international cultural event conceived by Carlo Quintelli, that was held in Parma, Modena, and Reggio Emilia for 10 years between 2004 and 2013. The organized events included seminars, exhibitions, roundtables, and webinars and involved hundreds of teachers, researchers, and students over the years, all belonging to different Italian and European faculties of architecture. The experience of the festival gave rise to the scientific magazine FAMagazine, research and projects on architecture and the city $<\mathrm{www}$.famagazine.it $>$. 
4 "Article 1 - Definitions: a. Landscape draws a certain part of a territory, as perceived by populations, whose character derives from the action and natural and/or human factors and their interrelationships."

5 In the project for the Program Plan of the Historic Center of Palermo, Samonà $(1984,81)$ speaks of the construction of the image of the city through patient and gradual work by adding units of meaning to the drawing sheet and defines this image as an intentional and significant icon:

Sometimes we stand before an object with certain research purposes, to analyze its meaning within a context that in many cases can be very complex; our descriptive analysis gives the object an intent related to a type of particular description, which gradually encodes the first image of it, and forms a second in which they are replaced with the signs of mere similarity of the various elements of the object, signs corresponding to the intent that is to be given to the new image, detecting characteristics of substance that influence its form and prepare a third image in which form tends to integrate into the substance itself to achieve the intentioned and significant unity of the image which we define icon, as the arrival point of the iconic process that began with the first naive image.

\section{Bibliography}

Amistadi, L. 2012a. Compact as redefinition. The semantic densification. In Compact City Architecture, Historical City Centre Design in Europe, eds. L. Amistadi and E. Prandi, 20-23. Parma: FAEdizioni. Amistadi, L. 2012b. La costruzione della città. Padua: Il Poligrafo.

Amistadi, L. 2008. Paesaggio come rappresentazione, seguito da Le metafore dell'architettura. Naples: Clean. Amistadi, L. 2018. The Limes or a space for foundation. In Founding and Refounding Parma, Reggio and Modena along the Roman Via Aemilia, ed. A. Morigi and C. Quintelli, 277-283 Padua: Il Poligrafo. Amistadi, L., and E. Prandi (eds.). 2011. European City Architecture. Structure, Project, Image. Parma: FAEdizioni.

Argan, G. C. 1982. La città nel pensiero di Leon Battista Alberti. Rassegna di Architettura e Urbanistica 54. Aymonino, C. 1975. Il significato delle città. Rome-Bari: Laterza.

Barthes, R. 1977. Frammenti di un discorso amoroso. Turin: Einaudi.

Council of Europe. 2000. European Landscape Convention, Florence.

De Carlo, G., and G. Samonà. 1984. Piano Programma del Centro Storico di Palermo 1979-1982. Progettare, Rivista trimestrale di architettura, urbanistica e pianificazione 1.

Grassi, G., and A. Rossi. 1970. Unità residenziale S. Rocco, Monza 1966, Relazione al progetto in concorso. Lotus 7.

Kociatkiewicz, J., and M. Kostera. 1999. The anthropology of empty space. Qualitative Sociology 1.

Le Corbusier. 1999. Verso un'architettura. Milan: Longanesi.

Muratori, S. 1960. Studi per un'operante storia urbana di Venezia. Rome: State Polygraph Institute.

Panofsky, E. 1955. Il significato nelle arti visive. Turin: Einaudi.

Rossi, A. 1966. L'architettura della città. Padua: Marsilio.

Rossi, A. 1982. The Architecture of the City. Cambridge, MA, and London: The MIT Press.

Samonà, G. 1980. Come ricominciare. Il territorio della città in estensione secondo una nuova forma di pianificazione urbanistica. Parametro 90.

Semerani, L. 2006. Dare un nome alle cose. In Giuseppe Samonà e la Scuola di architettura a Venezia. Padua: Il Poligrafo.

Ungers, O. M., and S. Vieths. 1997. La città dialettica. Milan: Skira.

Vignali, L. 2002. Dall'antica perduta cattedrale a San Petronio. L'evoluzione dell'architettura sacra a Bologna. Bologna: Arti Grafiche BFT. 